\title{
FORAMINIFERAL DISTRIBUTION IN TWO NOVA SCOTIA MARSHES
}

\author{
B. DEONARINE \\ Atlantic Geoscience Centre, Geological Survey of Canada \\ Bedford Institute of Oceanography, Dartmouth, Nova Scotia, Canada, B2Y 4A2
}

\begin{abstract}
Thirty sediment samples from marshes at Peggy's Cove and Clementsport, Nova Scotia, were examined and nine benthonic foraminifera species identified. Agglutinated tests form $98 \%$ of the total Foraminiferal population. Trochammina macrescens is the dominant form in upper marsh environments. This species is gradualiy replaced by Miliamina fusca as lower marst conditions are developed. M. fusca comprises $97 \%$ of the total population in the lower morsh environments scompled in this study.
\end{abstract}

\section{INTRODUCTION}

Marshes are marginal martne environments separating marine and continental areas. They are relatively widespread espectally along low relief coastlines and are usually well developed in estuaries and lagoons. Their landward and seaward boundaries are controlled by tidal amplitude. Marshes included in this study were not sampled quantitatively but qualitative results can be compared directly to more detailed information from nearby marshes (Scott and Medioli 1980a). The foraminiferal assemblages in two marshes located near Peggy's Cove and Clementsport were identified and compared (Figs. 1, 2, and 3). Unweighted pair-group cluster analysis (Sokal and Sneath 1963) was used for the analysis. The total foraminiferal percentages in sample pairs were compared using the Jaccard Coefficient of Association $\left(S_{f}\right)$ following the method used by Schafer and Scott (1976). The diversity index of foraminifera was calculated using the ShannonWeaver information function (H) where $H=\sum_{i=1}^{N} p_{i}$ ln $p_{i}$ and $p_{i}$ is the percentage of value of the $i$ th species; $N$ is the total number of species in the sample.

This diversity index is a function of both the number of species and the equality of species abundance in each sample.

\section{PREVIOUS STUDIES OF MARSH ENVIRONMENT}

Studies of the distribution of salt marsh foraminifera have increased substantially since 1950. Phleger investigated marshes in several areas of the world between 1950 and 1970. His studies (Phleger 1970) suggested that foraminiferal distribution data could be used to estimate tidal regime, current velocities, and water exchange in these environments. Work carried out before 1950 included that of Cushman and Bronnimann (1948) who described some new genera and species of foraminifera from inshore mud in mangrove swamps of the west coast of the Republic of Trinidad and Tobago. Recent marsh studies include that of steineck and Bergstein (1979). Their data, they believe, support the view that shallow-water foraminifers inhabit a 'living zone' extending $10 \mathrm{~cm}$ or more below the sediment surface.

Chapman (1960), MacDonald (1969), and Redfield (1972), among others, have described the vertical plant zonation in marsh environments. MacDonald (1969), using molluscs in his quantitative studies of salt marsh faunas from the North American Pacific coast, showed a distribution relationship between faunal and floral zones of west coast salt

marshes. The use of molluscs, however is comparatively unreliable in showing this relationship because their shells are calcareous and are easily

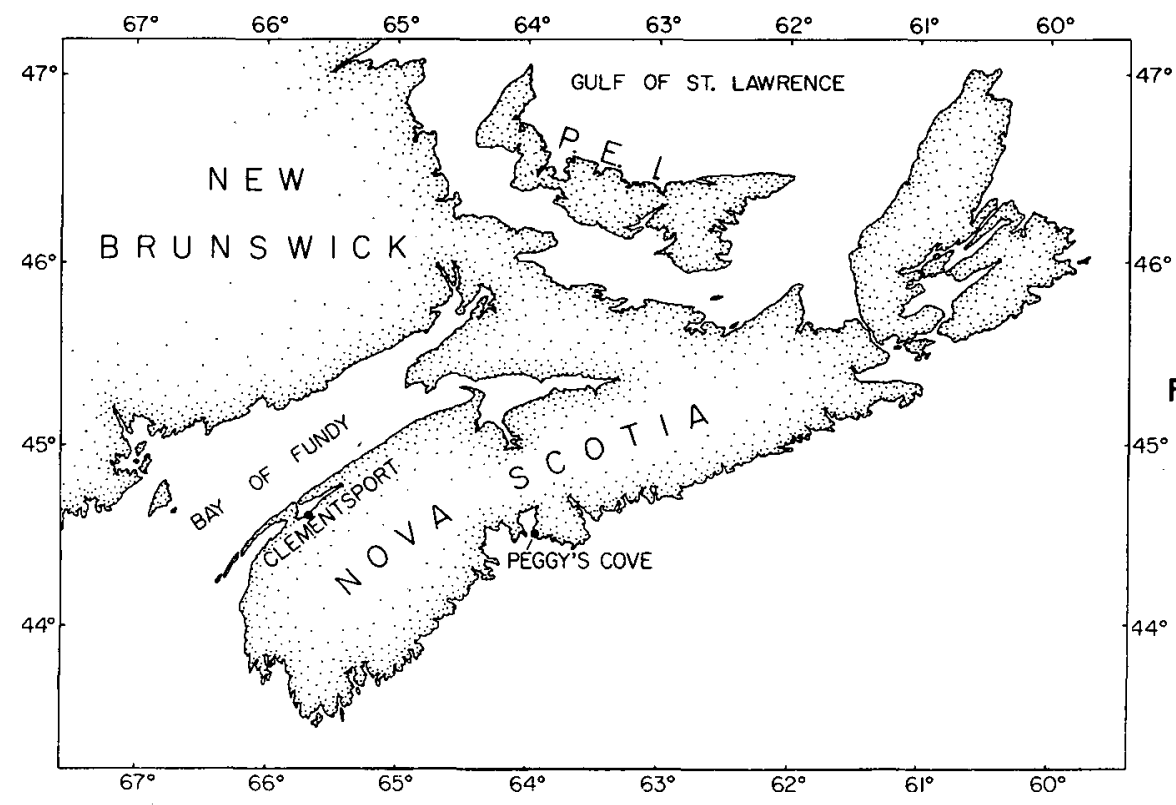

FIG. I Map of Nova Scotia with study sites. 
TABLE 1.

Foraminferal species distributions in relative percent and diversity in marshes of Peggy's Cove and Clementsport

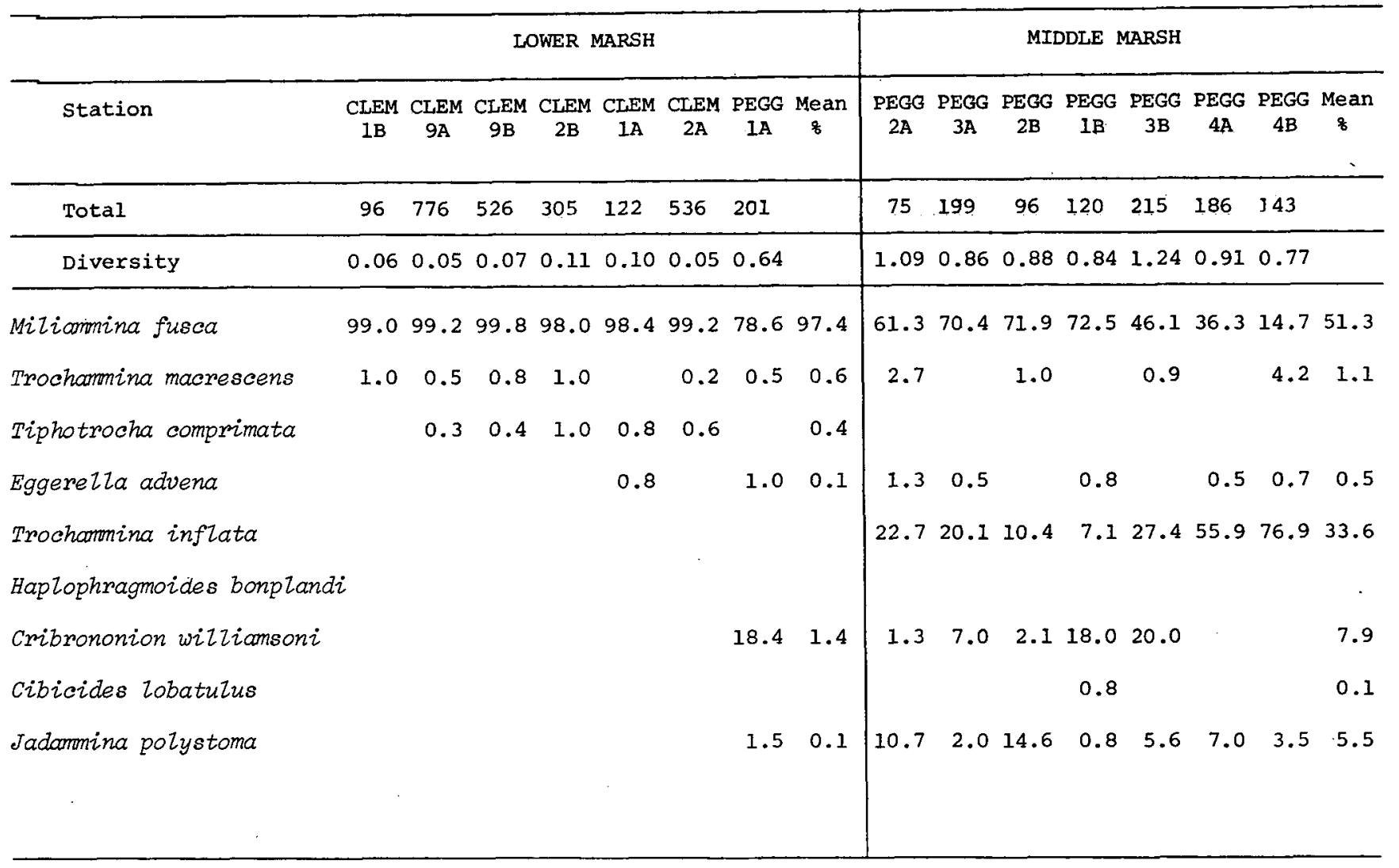

dissolved in low-pH marsh sediment. Scott (1976) demonstrated a relationship between flora and foraminiferal assemblages with sediment surface elevation in Southern California marshes, scott (1977) and scott and Medioli (1978, 1980a) have since illustrated the marsh foraminifera-sea level relationship for several locations in the Maritime Provinces.

Comparison of these published data with the results of this study confirm the association between foraminifera and flora in the Peggy's Cove and clementsport marshes.

\section{METHOD}

Surficial samples were collected at low tide using a.stainless steel corer (Scott 1977), and replicate samples of $10 \mathrm{~cm}^{3}\left(10 \mathrm{~cm}^{2} \times 1 \mathrm{~cm}\right)$ were obtained. To separate plants and other coarse materials from the foraminifera specimens the samples were wet-sieved through a $0.5 \mathrm{~mm}$ screen over a $0.062 \mathrm{~mm}$ screen. Samples were then fixed in $10 \%$ buffered formalin and stained with Rose Bengal. After washing, the foraminiferal samples were stored in denatured ethanol.

To obtain the total population, specimens were counted wet in a $5-\mathrm{cm}$ square tray that was divided into 12 equal areas. Micrographs of species dis- cussed in this paper were taken using the Cambridge Stereoscan 180 scanning microscope.

\section{MARSH ENVIRONMENTS}

Marsh areas, as distinct from intertidal mud flats, are covered with characteristic vegetation and occur between mean sea level to higher high watex (Chapman 1960). They can usually be subdivided into three vertical zones as a result of the duration and amplitude of tidal flooding in relation to elevation above mean sea level (Mac Donald 1969; Hinde 1954; Scott and Medioli 1978, 1980a).

In Nova Scotia (Fig. I) the typical upper marsh zone is usually inhabited by Spartina patens, Scirpus spp., and Solidago sempervirens, all of which are present in the upper marsh at clementsport (Fig. 3). The Peggy's Cove upper marsh (Fig. 2) supports Distichlis spp. and Scirpus spp. populations. Spartina patens which is common in middle marsh areas is also present in the middle marsh at Peggy's Cove (Fig. 2). However, this species was not present at clementsport. Lower marsh zones are often dominated by Spartina altermiflora and this species has been observed in this enviroment at Peggy's Cove and Clementsport (Figs. 2 and 3). 
TABLE 1. continued

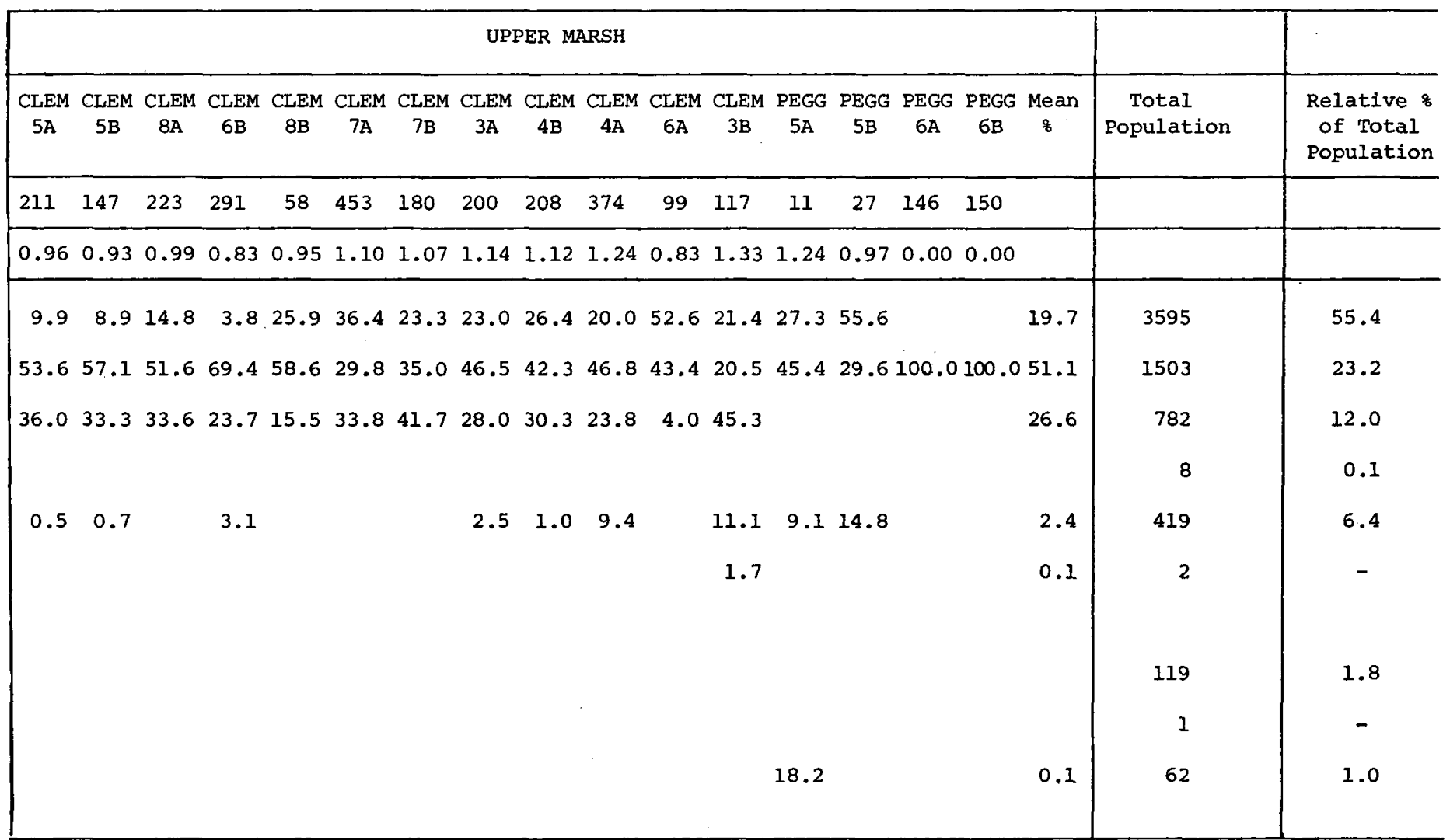

In addition to the vertical topographic gradient, marsh environments are subject to other phvsical gradients of parameters such as salinity, temperature, and $\mathrm{pH}$ which control the distribution of faunal and floral assemblages (Phleger and Bradshaw 1966).

\section{SPECIES AND ABUNDANCE}

Although samples were stained with Rose Bengal (to detect living specimens) only total assemblages are reported here. It has been shown (Scott and Medioli 1980b) that over a three-year period total assemblages were the most reliable indfeators of marine conditions in a Nova Scotian marsh, while living populations were irregular, both spatially and temporally.

Agglutinated tests form 988 of the total foraminiferal population at Peggy's Cove and Clementsport (Table 1). Miliarmina fusea comprises $55 \%$ of the total and is abundant in all assemblages. Trochamina macrescens accounts for $23 \%$ of the total population. A monospecific assemblage of $T$. macrescens occurs at stations PEGG $6 \mathrm{~A}$ and PEGG 6B. Tiphotrocha comprimata represents 128 and Trochammino inflata 68 of the overall population. The other species are less than $2 \%$ including the calcareous species, Cribrononion williamsoni and Cibicides lobatulus.

\section{RESULTS}

The cluster analysis suggested three thanatotypes in the Peggy's Cove marsh and two in Clementsport (Fig. 5). Peggy's Cove and Clementsport (Fig. 4) have three of six species common in the upper marsh ( $N$. fusca, $T$. macrescens and $T$. inflata). In the lower marsh they have two of six species common (T. macrescens and $E$. advena). The middle marsh at Peggy's Cove which is not observed at clementsport contains two calcareous of a total of seven species present (C. williamsoni and $C$. Zobatulus).

In the upper marsh thanatotope at Peggy's Cove and Clementsport (Fig. 5), six species were identified. Trochamina macrescens (51\%) is the dominant species with Tiphotrocha comprimata comprising $26 \%$ and Milianmina fusca 198 of the total population. The other species comprise less than $3 \%$ of the total population. This thanatotope corresponds with marsh zone IB of Scott and Medioli. 1978).

In the middle marsh thanantotope at Peggy's Cove seven species were identified. Milianmina fusca comprises $51 \%$ of the total population; Trochammina inflata 33\%, Cribrononion williomsoni 7\%, Jadommina polystoma 58; the other species proportions are below $2 \%$. This thanatotope corresponds with marsh zone IIA of Scott and Medioli (1978). 


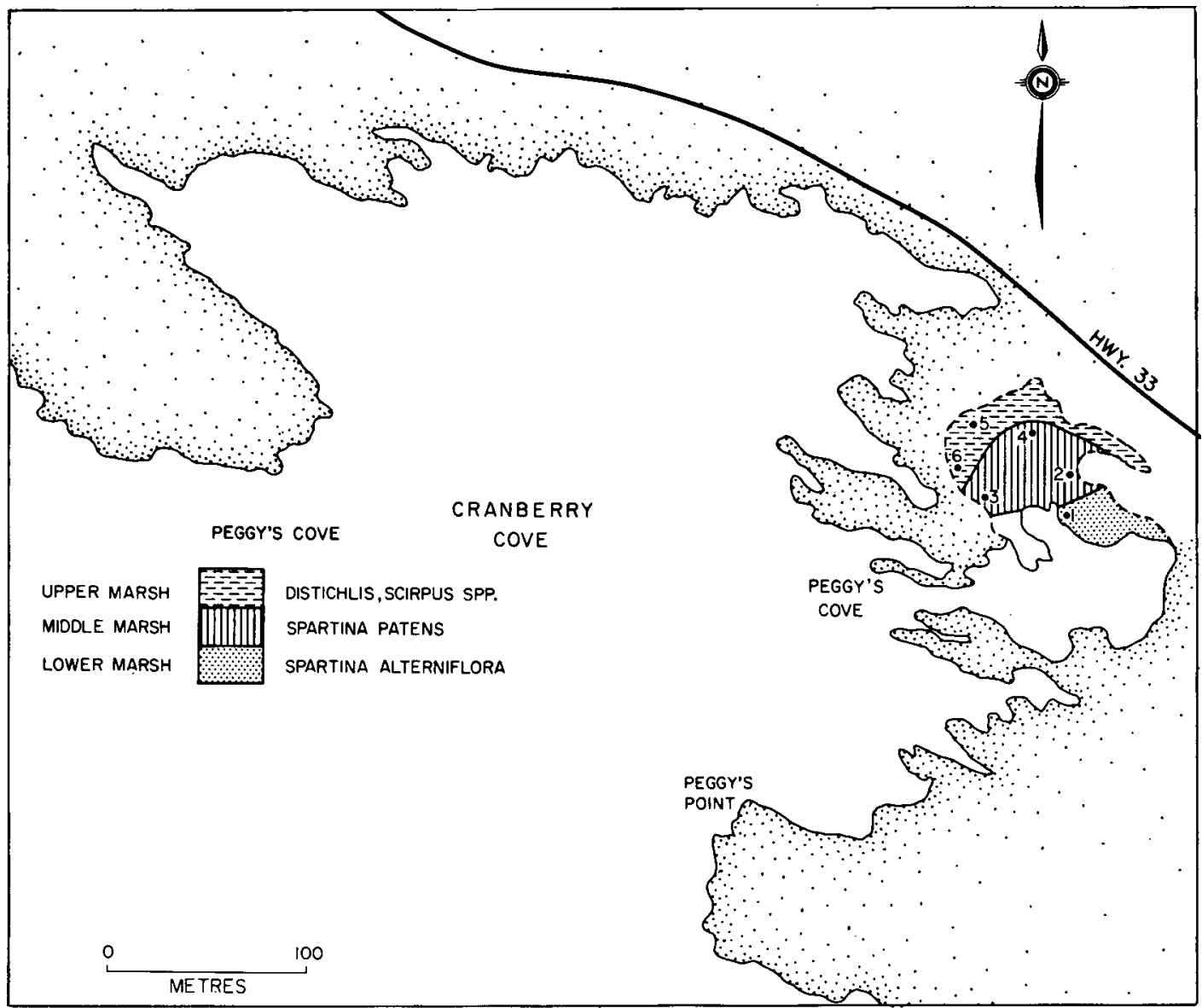

FIG. 2 Peggy's Cove.

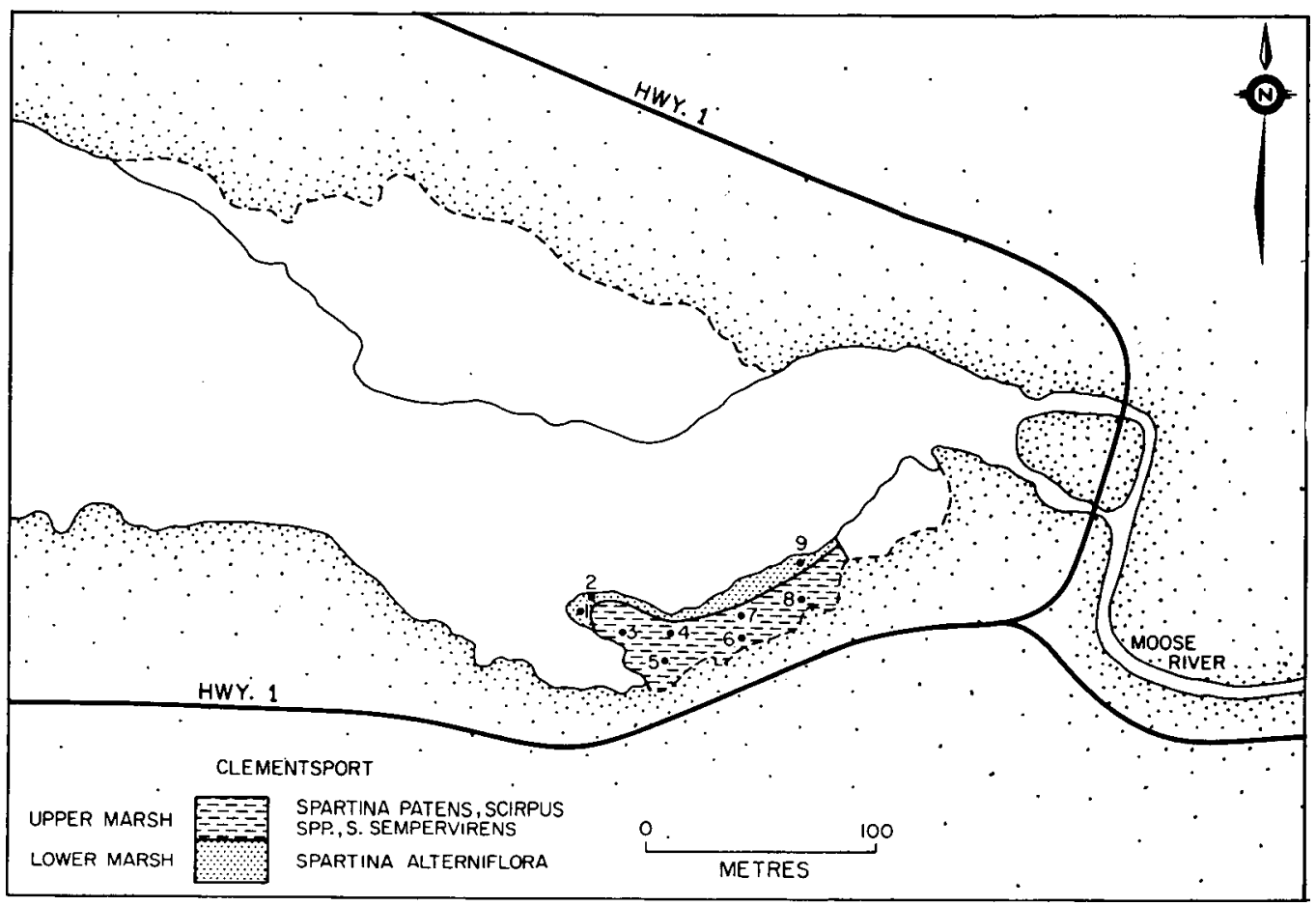

FIG. 3 Clementsport. 


\begin{tabular}{lllll}
\hline MARSH & VEGETATION & FORAMINIFERA & VEGETATION & FORAMINIFERA \\
\hline \multirow{2}{*}{ UPPER MARSH } & Distichlis & M. fusca & Spartina patens & M. fusca \\
& Scirpus & T. macrescens & Scirpus spp. & T. macrescens \\
& & T. inflata & S. sempervirens & T. inflata \\
& & & T. comprimata \\
& & & H. bonplandi
\end{tabular}

$\begin{array}{lll}\text { MIDDLE MARSH } & \text { S. patens } & \text { M. fusca } \\ & \text { T. macrescens } \\ & \text { T. inflata } \\ & \text { E. advena } \\ & \text { J. polystoma } \\ & \text { C. williamsoni } \\ & \text { C. Zobatulus } \\ & & \\ & & \text { M. fusca } \\ \text { LOWER MARSH } & \text { S. altemiflora } & \text { T. macrescens } \\ & & \text { E. advena } \\ & \text { J. polystoma } \\ & \text { C. wilizamsoni }\end{array}$

FIG. 4 Summary of Peggy's Cave and Clementsport marsh data.

In the lower marsh thanatotopes at Peggy's Cove and Clementsport, six species were identified. Miliammina fusca accounts for $97 \%$ of the total population followed by Cribrononion williamsoni the next highest at $1 \%$. This environment corresponds with marsh zone IIB of Scott and Medioli (1978). Relatively high diversity (1.33) and a high frequency of single species occurrences characterize the upper marsh thanatotope at Peggy's Cove and Clementsport (Table 1). In 14 of the 16 stations in the upper marsh the diversity ranges from 0.83 to 1.33. The other two monospecific stations (PEGG $6 \mathrm{~A}$ and PEGG $6 \mathrm{~B}$ ) are located in the uppermost part of the upper marsh. T. macrescens is the only species found there and is also abundant at most other stations in the upper marsh thanatotope. This assemblage corresponds with zone IA Scott and Medioli (1978). Middle marsh diversity ranges from 0.77 to 1.24 and the lower marsh diversity ranges from 0.05 to 0.64 . The dominant species in these two environments is $M$. fusca.

\section{CONCLUSIONS}

1. The cluster analysis method resolves three major thanatotopes for the two marshes at a similarity index level of 0.49 .

2. The more important indicator species in each of the thanatotopes are usually part of a ubiquitous association. These include $T$. carescens and $T$. comprimata in the upper marsh, $M$. fusca and $T$. inflata in the middle marsh and $M$. fusca in the lower marsh.

3. The foraminiferal thanatotopes subdivide the marshes into zones that are comparable aerially with their floral distributions. The main floral species in the upper marshes, Distichlis and Scirpus at Peggy's Cove and Solidago sempervirens and Scirpus spp at Clementsport are associated with $T$. macrescens. In the middle marsh thanatotope, T. inflata and $M$. fusca are the most abundant species in Peggy's Cove where $S$. patens is common. $M$. fusca is assoctated with $S$. altemiflora, the grass which predominates in the lower marsh thanatotope at Both Peggy's Cove and Clementsport.

4. Population diversity appears to decrease from the upper marsh to the lower marsh except at Stations PEGG $6 \mathrm{~A}$ and PEGG $6 \mathrm{~B}$, the area where the characteristic monospecific zone IA was encountered (Scott and Medioli 1978). The diversities observed in all zones compare favorably with those of scott and Medioli (I980a) except that they recorded more species in low marsh areas. The middle marsh is a transition area where some species either reach theix upper or lower limit of distribution within the marsh gradient. Hence, diversity here could be expected to be higher. However, the apparent lower diversities in the low marsh may be the result of inadequate sampling (seven samples total in low marsh versus sixteen in the upper marsh).

5. The upper marsh foraminiferal assemblage comprises 100\% agglutinated species. Foraminiferal assemblages in the middle and lower marshes are also dominant in agglutinated species, but include a small percentage of the calcareous form $C$. williamsoni. In general, absence of calcareous species can probably be attributed to low $\mathrm{pH}$ levels and low salinities that prevail in the upper marsh sediment.

6. The Clementsport marsh is characterized by a distinct upper and lower marsh assemblage. Peggy's Cove shows an upper, middle, and lower marsh assemblage. The middle marsh thanatotope in Peggy's Cove is represented by $M$. fusca, T. macrescens, T. inflata, $E$. advena, $J$. polystoma, $C$. williamsoni and $C$. lobatulus. This assemblage was not evident in clementsport but may have been missed due to an in- 


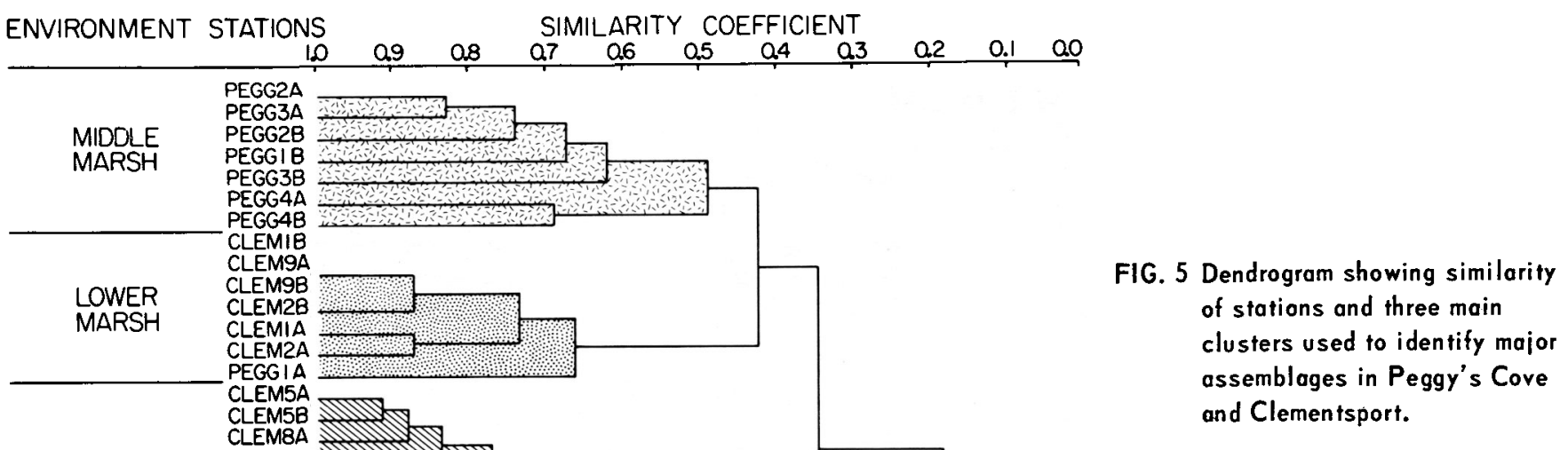

sufficient number of sampling stations.

7. Trochomina macrescens comprises the total population at stations PEGG 6A and PEGG 6B of the upper marsh at Peggy's Cove. This assemblage has been shown to occur only in the upper 5 crn of the tidal range in Nova Scotia by Scott (1977) and scott and Medioli (1978, 1980a). A combination of elevation (i.e. exposure) and lowered salinities probably influences the development of this species: to the complete exclusion of other marsh forms.

\section{ACKNOWLEDGEMENTS}

Thanks are expressed to Professor Franco Medioli and Dr. Gustavs vilks for direction in preparing the data for this paper. spectal thanks are extended to Dr. David Scott who collected the samples for study, and espcially Dr. Charles Schafer for critically reading the manuscript and for valuable suggestions.

\section{REFERENCES}

BARIENSTEIN, H. and BRAND, E. 1938. Die Foramintferan-Fauna des Jade-Gebietes I. Judanmina polystoma n.g.. n.sp. aus dem Jade-Gebietes (for): Senckenbergiana. vol. 20. n. 5 . pp. 381-385.

BRADY, H.B. 1870, in Brady, G.S., and Robertson, D. 1870. The ostracoda and Foramintfera of tidal rivers. With analysis and descriptions of Foraminifera by н.B. Brady, part II; Annual Magazine of Natural History. Ser. 4, vol. 6, pp. 273-306.

CHAPMAN, V.J. 1960. Salt marshes and salt deserts of the world: Leonard Hill LTP, London, $392 \mathrm{pp}$.

CUSHMAN, J.A. 1921. Results of the Huason Bay expedition, 1920; I - The Foraminifera: Toronto, Canada. Biological Board, Contributions to Canadian Biology (1921), 1922, no. 9, pp. 135-147.

1931. The Foraminifera of the Atlantic Ocean, pt. 8: Rotaliidae, Amphisteginidae, Calcarinidae, Cymbaloporettidae, Globorotal- iidae, Anomalinidae, Planorbulinidae, Rupertilidae and Homotremidae: U.S. National Museum Bulletin, vol. 104 , part $8 .$, p. 118 .

1937. A monograph of the foraminiferal Family valvulinidae: Cushan Laboratory for Foraminiferal Research Spectal Publication 8, $210 \mathrm{pp}$.

CUSHMAN, J.A. and BRONNIMANN, P. 1948. Some new genera and species of Foraminifera from brackish water of Trinidad: Cush. Lab. Foram. Res. Contrib., Vol. 24, pp. 15-21.

HAYNES, J.R. 1973. Cardigan Bay Recent Foraminifera: Bulletin of the British Museum (Natural History), Zoology. Supp. 4, 245 pp.

HINDE, H.P. 1954. Vertical distribution of salt marsh Phanerogams in relation to tide levels: Ecol. Monogr., 24, pp. 209-225.

LEVY, A., MATHIEU, R., MOMENI, I., POIGNANT, A., ROSSET-MOULINIER, M., ROUVILILOIS, A., and UBALDO, M. 1969. Les représentants de la Famille de Elphidiidae (Foraminiferes) dans les sables des plages des environs de Dunkerque. Remarques sur les espèces de Polystomella signalees par o. Terquem: Revue de Micropaleonotologie. vol. 12 , n. 2, pp. 92-98.

MacDONALD, K.B. 1969. Quantitative studies of salt marsh faunas from the North American Pacific coast: Ecol. Monogr., vol. 39, n. 1, pp. 33-60.

MONTAGU, G. 1808. Testacea Britannica, supplement: Exeter, England, S. Woolmer, $183 \mathrm{pp}$.

MURRAY, J.W. 1971b. An Atlas of Recent British Foraminiferids, New York: Elsevier Publishing Co.

NORVANG, A. 1945. The zoology of Iceland, Foraminifera vol. 2, part 2, pp. 1-79, Copenhagen and Reykjavik, E. Munksgaard.

PARKER, W.K. and JONES, T.R. 1859. On the nomenclature of the Foraminifera, part 2, on species enumerated by Walker and Montagu: Annual Magazine of Natural History, ser. 2, vol. 4, pp. 333-351.

PHLEGER, F.B. 1970. Foraminiferal populations and marine marsh processes: Limol., Oceanogr., vol. 15, n. 4, pp. 522-534.

PHLEGER, F.B. and BRADSHAW, J.S. 1966. Sedimentary environments in a marine marsh: Science, vol. 
$154, \mathrm{n}, 3756, \mathrm{pp}, 1551-53$.

PHELGER, F.B. and WALTON, W.R. 1950. Ecology of marsh and bay Foraminifera, Barnstable, Mass.: American Journal of Science, vol. 248, pp. $274-294$.

REDFIELD, A.C. 1972. Development of a New England salt marsh: Ecol. Monogr., vol. 42, n. 2, pp. 201-237.

SANDERS, J.B. 1957. Trochamminidae and certain Lituolidae (Foraminifera) from the recent brackish-water sediments of Trinidad, British West Tndies: Smithsonian Miscellaneous Collections, vol. 134, n. 5, publ. 4270, pp. $1-16$.

SCHAFER, C.T. and SCOTT, D.B. 1976. Multidisciplinary environmental marine geological analysis of a coastal area: Geol. Surv. Canada Paper, 76-1C.

SCOTT, D.B. 1976. Quantitative studies of marsh foraminiferal patterns in southern California and their application to Holocene stratigraphic problems: First Inst. Symp. on Benthonic Foraminifera of Continental Margins, Part A, Ecology and Biology, Maritime Sediments Spec. Publ. 1, pp. 153-170.

SCOTT, D.B. 1977. Distributions and population dynamics of marsh-estuarine foraminifera with applications to relocating Holocene sea levels: Dalhousie University, Halifax, N.S., Ph. D. dissertation, 252 pp.

SCOTT, D.B. and MEDIOLI, F.S. 1978. Vertical zonations of marsh foraminifera as accurate indicators of former sea levels: Nature, vol, 272, n. 5653, pp, 528-531.

1980a. Quantitative studies of marsh foraminiferal distributions in Nova Scotia implications for sea level studies: Cush. Found. for Foram. Res.Spec. Publ. no. 17, $58 \mathrm{pp}$.

1980b. Living vs. total foraminiferal populations: their relative usefulness in paleoecology: J. Paleo., vol. $54, \mathrm{n} .4$, pp. 814-831.

SOKAL, R.R. and SNEATH, P.H. 1963. Principles of numerical taxonomy. Freeman, San Francisco, C.A., 359 pp.

STEINECK, P.L, and BERGSTEIN, J. 1979. Foraminifera from Hammocks Salt-Marsh, Larchmont Harbor, New York: J. Foram. Res., vol. 9, n. 2, pp. 147-158.

TODD, R. and BRONNIMANN, P. 1957. Recent Foraminifera and Thecamoebina from the Eastern Gulf of Paria: Cushman Foundation for Foraminiferal Research Special Publication 3, 43 pp.

WALKER, G. and JACOB, E. 1978. In Kanmacher, F., Adams' Essays on the microscope. Ed. 2, London, England, printed by Dillon and Keating, p. 642 .

WILLIAMSON, W.C., 1858. On recent Foraminifera of Great Britain: Royal Society (London) Publication, $107 \mathrm{pp}$.

\section{APPENDIX}

Systematic Taxonomy

Species are listed below in alphabetical order. Refer to Plates 1 and 2 for micrographs of the species. The original and subsequent references are also listed below for each of the nine species identified.

CIBICIDES LOBATULUS (Walker and Jacob), Plate I, Figures 8, 9

Nautilus Zobatulus Walker and Jacob in Kanmacher, 1798 , p. 642, p1. 14, fig. 36.

Cibicides Zobatula (Walker and Jacob). Cushman, 1931, p. 118, pl. 21, fig. 3a-c.

Cibicides lobatulus (Walker and Jacob). Norvang, 1945, p. 49, pl. 6, fig. 26a.

CRIBRONONION WILLIAMSONI (Haynes), Plate 1, Figures 10, 11

Polystomelza umbilicatula williamson, 1858, p. 4244, fig. 81-82.

Elphidium umbilicatulum (Williamson). Levy et al., 1969, p. 96, pl. 1, fig. 62, b, pl. 2, fig. 1, 2 . Elphidium williamsoni Haynes, 1973, p. 207-209 pl. 24, fig. 7: pl. 25 fig. 6 \& 9, pl. 27, fig. 1-3.

EGGERELLA ADVENA (Cushman), Plate 1, Figure 4.

Vemeuilina advena Cushman, 1921, p. 141.

Eggerelza advena (Cushman). Cushman, 1937, p. 51, pl. 5, fig. 12-15.

HAPLOPHRAGMOTDES BONPLANDI TOdd and Bronnimann, plate 2, Figures 9, 10

Haplophragmoides bonplandi Todd and Bronnimann, 1957, pl. 23, pl. 2, fig. 2; scott et al., 1977, p. $1579, \mathrm{pl} .3$, fig. 5,6 .

JADAMMINA POLYSTOMA Bartenstein and Brand, Plate 1, Figures $5,6,7$

Jadomina polystoma Bartenstein and Brand, 1928, p. 381, fig. $1 a-c, 2 a-1,3$.

MILTAMMTNA FUSCA (Brady), Plate 1, Figures 1, 2, 3

Quinqueloculins fusca Brady, 1870, p. 47, p1. 11, fig. $2,3$.

Miliamia fusca (Brady). Phleger and Walton, 1950, p. 280, pl. 1, fig. 19a, b.

TIPHOTORCHA COMPRTMATA (Cushman and Bronnimann) emend. Saunders, 1957, Plate 2, Figures 7, 8.

Trochanmina comprimata Cushman and Bronnimann, 1948a, p. 41, pl. 8, fig. 1-3.

Tiphotrocha comprimata (Cushman and Bronnimann). saunders, 1957, p. 11 .

TROCHAMMINA INFLATA (Montagu), Plate 2, Figures $1,2,3$.

Nautilus inflatus Montagu, 1808, p. 81, pl. 18, fig. 3 .

Trochamina inflata (Montagu). Parker and Jones, 1859 , p. 347 .

TROCHAMMINA MACRESCENS Brady, Plate 2, Figures 5 , 5,6

Trocharmina inflata (Montagu) var. macrescens Brady, 1870, p. 290, pl. 11, fig. 5, 7. Jadomina macrescens (Brady). Murray, 1971b, p. 41, pl. 13, fig. 1-5. 
PLATE 1

(Scanning Electron Micrographs)

Figures 1-2. Miziammina fusca (Brady)

1. side view (four chamber side), $\times 94$

2. side view (three chamber side), $\times 140$

3. aperture view, $\times 225$

Figure 4. Eggere Zla advena (Cushman)

4. side view, $\times 244$

Figures 5-7. Jadommina polystoma Bartenstein and Brady

5. ventral view, $\times 162$

6. aperture view, $\times 150$

7. dorsal view, $x 280$

Figures 8-9, Cibicides lobatulus (Walker and Jacob)

8. dorsal side, $\times 112$

9. ventral sixe, $\times 134$

Figures 10, 11. Cribrononion williamsoni (Haynes)

10. aperture view, $\times 180$

11. side view, $\times 112$ 


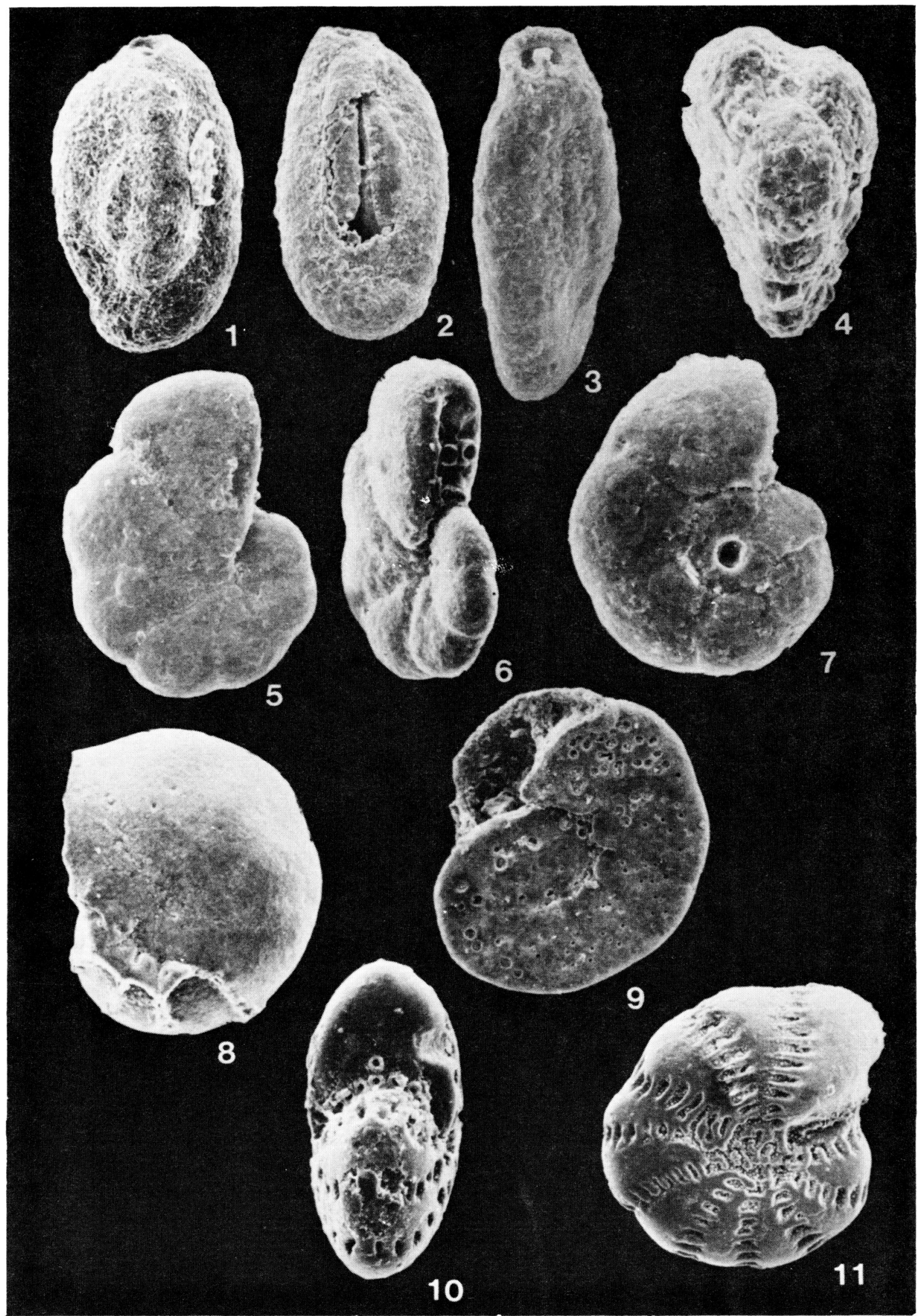


PLATE 2

(Scanning Electron Micrographs)

Figures I-3. Trochammina inflata (Montagu)

1. dorsal view, $\times 105$

2. aperture view, $\mathrm{x} 98$

3. ventral view, $\times 118$

Figures 4-6. Trochammina macrescens Brady

4. dorsal view, $x 176$

5. aperture view, $\mathrm{x} 162$

6. ventral view, $x 131$

Figures: 7-8. Tiphotrocha comprimata (Cushman and Bronnimann)

emend. Saunders, 1957

7. dorsal view, $\times 112$

8. ventreal view, $\times 160$

Figures 9-10. Haplophragmoides bonplandi Todd and Bronnimann

9. side view, $x 186$

10. ventral view, x 232 . 


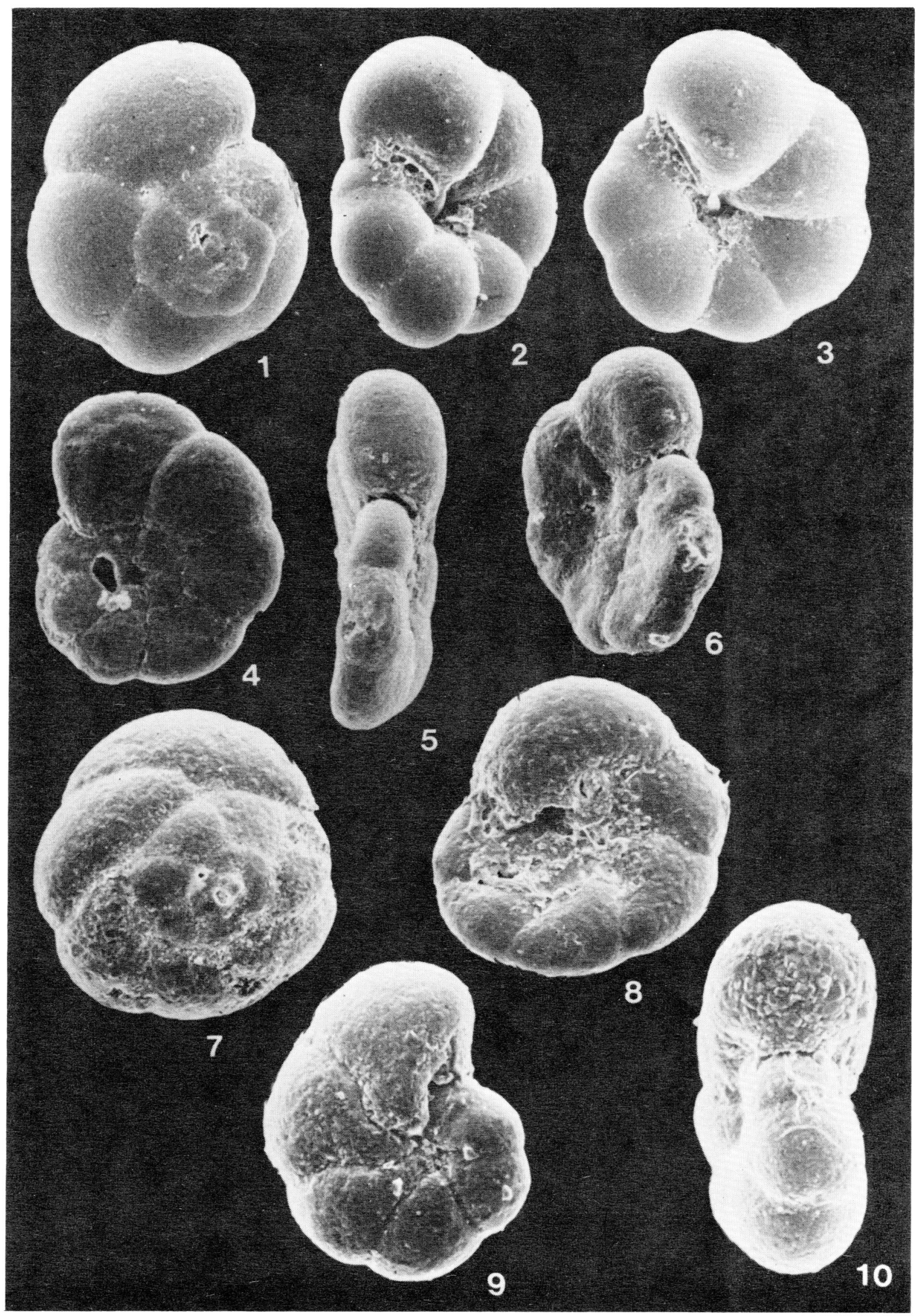

